\begin{tabular}{|c|c|c|c|c|c|}
\hline $\begin{array}{c}\text { Compound } \\
\text { used }\end{array}$ & Tumour & $\begin{array}{c}\text { No. of } \\
\text { mice } \\
\text { treated }\end{array}$ & $\begin{array}{c}\text { Total } \\
\text { wt. of } \\
\text { tumours } \\
\text { (gm.) }\end{array}$ & $\begin{array}{c}\text { No. of } \\
\text { controls }\end{array}$ & $\begin{array}{c}\text { Total } \\
\text { wt. of } \\
\text { tumours } \\
\text { (gm.) }\end{array}$ \\
\hline $\begin{array}{c}\text { (1) Adenylic } \\
\text { acid } \\
\text { (2) Guanylic }\end{array}$ & $C 57$ & 51 & $179 \cdot 6$ & 51 & $291 \cdot 8$ \\
$\begin{array}{c}\text { acid } \\
\text { (3) Gaanylic }\end{array}$ & $C B A 1$ & 23 & $16 \cdot 8$ & 23 & $42 \cdot 7$ \\
$\begin{array}{c}\text { acid } \\
\text { (4) Cytidylic }\end{array}$ & $C 57$ & 31 & $132 \cdot 2$ & 31 & $202 \cdot 0$ \\
acid \\
$\begin{array}{c}\text { (5) Uridylic } \\
\text { acid } \\
\text { (6) Sodium } \\
\text { phosphate }\end{array}$ & $C 57$ & 30 & $152 \cdot 0$ & 30 & $157 \cdot 3$ \\
\hline
\end{tabular}

guanylic acid appearing to cause a considerable increase of giant cells per unit area. The number of these cells in spleens of mice treated with uridylic acid were comparable with those found in the controls. No estimation of the number of giant cells per unit area in the spleens
of mice of Group 2 was made owing to the prevalence of amyloid inflitration of this organ.

Normal mice. Normal stock or pure-line mice treated with adenylic or cytidylic acid showed a considerable rise in the total white tolood cell count within twenty-four hours of the initial injection. This leucocytosis was maintained with some fluctuation throughout the period of treatment. Absolute values of lymphocytes, polymorphs and immature myeloid cells were increased, with frequent crossing of the lymphocyte line by that of the polymorph. A rise in the number of eosinophils was infrequent and never exceeded 6 per cent. Amyloid infiltration of spleen and liver was noted in mice treated with adenylic acid, but not in those injected with cytidy

plasmacytosis of lymph nodes was usual.
Mice treated with guanylic acid showed either a slight initial rise or fall in the total white blood-cell count within twenty-four hours or fall in the total white blood-cell count within twenty-four hours
after the first injection. Successive doses failed to cause more than a moderate leucocytosis. Crossing of the lymphocyte line by that a moderate leucocytosis. Crossing of the lymphocyte line by that the number of eosinophils was a marked feature, often totalling the number of eosinophils was a marked feature, often totalling liver and spleen was also noted, with plasmacytosis and reticulosis of lymph nodes.

Iron-reacting material and non-iron-reacting pigment were usually found in the lymph glands and spleens of all the mice treated with the three nucleotides. Further investigation in relation to splenic weights and number of giant cells is being carried on.

The systemic effects of the growth of primary and grafted sarcomas have already been described ${ }^{2}$. These include a leucocytosis often of leukæmic proportions, an increase of myeloid cells with crossing of the lymphocyte and polymorph lines, reticulosis and plasmacytosis of lymph nodes, iron-reacting deposits in lymph glands, liver and spleen, and amyloid infiltration of spleen and liver. Mice undergoing treatment with carcinogenic compounds show a sudden, temporary and large increase of eosinophils in the blood, usually during the latter half of the latent period and before tumour development.
Iron-reacting material is found to be progressively deposited in their lymph nodes

It seems therefore that a combination of the responses of the tissues of normal mice to the administration of the individual pentose nucleotides reproduces with a singular exactness the systemic effects of tumour-growth, and it is difficult to exclude the possibility that pentose nucleotides may be liberated in the body during the development of primary or grafted sarcomas and induce the tissue changes mentioned the nucleic acid content of tumours and that of the normal tissues of origin ${ }^{3}$.

Experiments are in progress to investigate the relationships between the molecular structure of the nucleotides and these biological effects.

We are grateful to the British Empire Cancer Campaign for grants which have defrayed the cost of this investigation. G. R. BAREER.

Bernhard Baron Institute of Pathology, I. D. PARSONS.

The London Hospital, London, E.1; Jan. 10 .

1 Parsons, L. D., J. Path. and Bact., 57, 9 (1945).

2 Clarkson, J. R., Mayneord, W. V., and Parsons, L. D., J. Path. and Bact., 48, 221 (1938). Mayneord, W. V., and Parsons, I. D., (1936); 47, 501 (1938); 54, 321 (1942) ibid., 40, 45 (1935); 43, L. D., and Warren, F. L., ibid., 52, 305 (1941).

${ }^{3}$ Davidson, J. N., and Waymouth, C., Brit. J. Exp. Path., 25, 164 (1944) and references therein.

Effect of Acute Starvation on the Adrenals of the White Rat

SrNCE McCarrison ${ }^{1}$ in 1919 and Vincent ${ }^{2}$ in 1920 recorded the enlargement of the adrenals in the pigeon and the rat as a result of a cute starvation, this anomalous result has been generally considered

a hypertrophy , $^{3}$, no other tissue enlarges from such treatment.
We have shown that rats, given water but no food, develop a typical We have shown that rats, given water but no food, develop a typical behaviour syndrome two or three days before death, in which at frst they exhibit increased activity, and afterwards old animals show
marked immobility. At this pre-mortal stage in old animals or the marked immobility. At this pre-mortal stage in old animals or the
corresponding stage in younger rats, they have lost 30 per cent or more of their body-weight, and if they are killed the adrenals are found to be enlarged and discoloured to a dark grey or dark dirty grey. The enlarged glands contain an increased amount of water, though their solid content remains practically unaltered. In sections of the glands, cell nuclei counts in comparable areas measured from the periphery of the cortex inwards show a decrease when compared with normals. The change thus appears to be largely due to an increase in the water content of the cells. The glomerular zone is decreased in thickness and the reticular zone shows some signs of degeneration.

Hence adrenal enlargement in the pre-mortal stage of inanition appears to be a pathological process, perhap

degeneration, and is not a hypertrophy. till have adrenals normai in size, water content and colour.

Data in the literature suggest that certain types of adrenal enlargement such as that produced in the pigeon adrenal by deflciency of vitamins of the B-complex may be similar in nature, with discolora-
tion $^{5}$, increased water content t $^{5}$ and diminished cell nuclei in equal

The details of our experiments are in course of publication.

The details of our experiments are in course of publication.
A. T. CAMrERoN.
J. CARMICHAEL.

Department of Biochemistry,

Facuity of Medicine,

University of Manitoba,

Winnipeg.

${ }^{1}$ McCarrison, R., Indian J. Med. Res., 6, 275 (1919).

Vincent, S., and Hollenberg, M. S., Endocrin., 4, 408 (1920); J. Physiol,, 54, P. lxix (1920-21).

${ }^{3}$ Tepperman, J., Engel, F. L., and Long, C. N. H., Endocrin., 32,

373 (1943)" A., "Adrenal Glands in Health and Disease" (Phils.,
"Goldzieher, M. A., "Ad

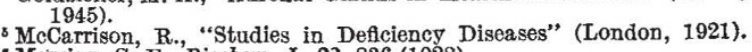
- Marrian, G. F., Biochem. J., 22, 836 (1928).

\section{Water Exchange between Insects and Air Moisture}

IT is well known that the weight of some fasting insects increases when they are exposed to an atmosphere saturated with water vapour. This phenomenon is generally considered to be due to the absorption of moisture from the air, and the insects concerned, such as Leptino"hygroscopic'. The weight change is obviously influenced by a series
of factors. In order to isolate the factor of 'hygroscopicity', we have kept the insects in air saturated with water vapour, the vapour being derived from water containing 8 per cent of heavy water ; the vapour also contains 8 per cent of heavy water. The concentration of heavy also contains 8 per cent of heavy water. The concentration of heavy water in the insects was determined after va

Several species of insect were used. Some lose weight while fasting in saturated air ; for example, Tenebrio molitor (Col.), adult; Graphosoluter similar conditions: for example, Tenebrio molitor (Col.), larva ; Leptinotarda decemilineata (Col.), adult.

We found that, to our surprise, the body water of all these insects, whether or not the are 'hygroscopic' comes into equilibrium with whet or not they are hygroscopic, comes into equilibrium their water in the form of heavy water, in the course of a few days. This watibrium is reached in thirteen days in the case of Tenebrio larva, nine days for the adults of the same species and for those of Leptinotarsa; flive days for the adults of Graphosoma.

The only possible conclusion from these observations is that, under the conditions the atmospheric and 'non-hygroscopic' insects. The body-water is, within a few days, completely replaced hy water molecules from the atmosphere.

We are indebted to Prof. M. Florkin for suggesting the use of heavy water vapour.

\section{J. GOVAERTS.
J. LECLERCQ.}

Laboratories of Biochemistry and Radioactivity, University of Liège.

1 Breitenbrecher, Pub. Carnegie Inst. Washington, 233, 34 (19.18).

Bodine, J. Exp. Zool. 32, 137 (1921).

- Wigglesworth, Proc. Ent. Soc. London, ser. B, C, 25 (1931).

Wigglesworth, Proc. Ent. Soc. London, ser. B, C, 25 (1931).

S Ruxton, Proc. Roy. Soc. London, ser. B, 108, S60 (1930). Carlsberg, 23 $17(1938)$.

\section{Rat Vectors of Plague}

IN view of the abundant evidence that Rattus norvegicus is a vecto of plague $\theta^{1}$ it is perhaps of interest to record an outbreak not associated with this rat.

In Rangoon, immediately after the British reoccupation in May 1945 , seventeen cases of human plague occurred between May 15 and Angust 29. Of these, eleven occurred in the district of Bahan to the north and west of the Royal Lake, two from the centre of the from villages outside the town. It is possible that in fact all cases were contracted in Bahan.

Rats from all parts of Rangoon were examined, and it was found that Rattus norvegicus occurred in the docks and town, but did not appear north of Kantawgale, a district to the south of the Royal Lake. It was absent from both Bahan and Kemmendine. Of 671 rats trapped and poisoned in Bahan, the percentage of different species is shown in the accompanying table. In this table is also shown the mean number of fleas per rat of 229 from Bahan and elsewhere, examined in August. 